Copyright (C) 2014 by Academic Publishing House Researcher

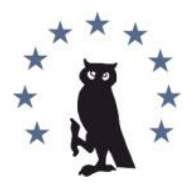

Published in the Russian Federation

European Researcher

Has been issued since 2010.

ISSN 2219-8229

E-ISSN 2224-0136

Vol. 85, No. 10-2, pp. 1858-1864, 2014

DOI: $10.13187 / \mathrm{er} .2014 .85 .1858$

www.erjournal.ru

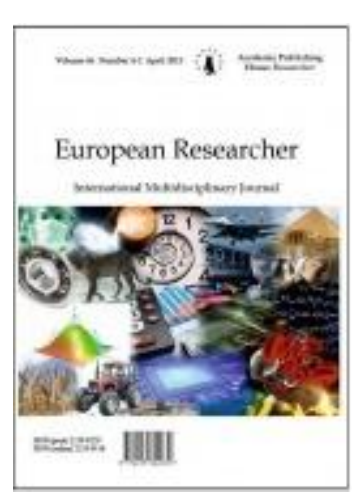

Pedagogical sciences

Педагогические науки

UDC 371

\title{
The Influence of Selected Exercises on Level of Explosive Strength of Lower Limbs of Pupils in Volleyball Preparation
}

\author{
${ }^{1}$ Lukáš Šmída \\ ${ }^{2}$ Robert Rozim \\ 3 Elena Bendíková
}

1-3 Matej Bel University, Slovakia

The Faculty of Arts

Tajovského 40, 97401 Banská Bystrica

${ }^{1}$ E-mail:lukas.smida@gmail.com

${ }^{2}$ Dr. (Pedagogic Sciences), PhD.

E-mail: Rober.Rozim@umb.sk

3 Doc. Dr. (Pedagogic Sciences), PhD, Ass. Professor

E-mail: Elena.Bendikova@umb.sk

\begin{abstract}
Aim of survey was to verify influence of selected compilation of exercises in sport preparation of pupils in volleyball preparation VK TatranBanská Bystrica on their explosive strength of lower limbs. We tried to use measurements with device Myotest to see how it affects on level of development of explosive strength of lower limbs by selected specific compilation of exercises. Our experimental group was consisted of 14 male pupils between ages of 12 to 15 years. Between input and output evaluation our research group participated on total of 84 training units, of which 56 were classified as training exercises from our compilation of exercises. Result of application of created sports training on pupils in VK Tatran Banská Bystrica is total increase of level of explosive strength of lower limbs in our research group, but it was not statistically significant in some parameters which underlie listed determinant.

Listed partial discoveries are included in the grant: VEGA no. 1/0376/14 Intervention as physical activity as health prevention of Slovak population.

Keywords: Volleyball; Explosive strength; Lower limbs; Older pupils.

\section{Introduction}

Need for physical activities is natural for humans being, which is carried out at different levels and ways as well in sport, acting on individual areas of personality. One of these sports is also
\end{abstract}


volleyball, which affect on us comprehensively in all its form. Without distinction of sex and age, which does not belong to financially demanding collective sports.

To primary determinant of quality performance in volleyball belongs as well high-quality sports training, just like in other sports, which builds on development of technics of individual sport activities, whether on development of physical ability with intention to dynamic and explosive characteristics. Those are in the game reflected mainly in hitter's and blocker's jumps, quick starts, movements and falls.

Dynamic strength is base of vertical jumping, which is main building pillar of collective game - volleyball (Vavák, 2011). Authors Choutka, Dovalil (1987), Sýkora et al. (1995), Zemková, Hamar (2005), Doležalová, Lednický (2006), Šimonek (2007) and others consist that explosive strength is is characterized by muscular exertion, in which we are trying to create as much power as possible per unit of time. It is the ability to give your own body or subject highest acceleration. In this case it is about various jumps, reflections, throws, etc. In volleyball it is used for start and reflection and for active hit to ball. Vavák (2011) says that eccentric contraction, active stretching is changed in shortest time with concentric contraction. Just bigger production of power due to use of the elasticreflective mechanisms of the musculo-tendinous system points to necessity of as fast as possible transition from tension to contraction. Otherwise, there is reduction of strength generation. Sedláček, Lednický (2010) list that explosive strength create muscle performance, where cycle of tension and subsequent contraction of muscle causes increase of power impulse, which depends on speed of muscle contraction, level of maximum strength and its flexibility, which are given to body or its individual parts over high acceleration. According to Vanderka (2008) not only in terms of speed of execution, but also mechanism of individual muscle groups participation in so-called myofasial loops have in terms of increasing speed-power manifestations considerable importance, and therefore have so-called complex multi-joint, weight-bearing exercises better system effect with impact on larger number of muscle groups.

Reflection can be divided into two phases, which Šimonek (1980) describes as a amortization and active phase. First amortization phase begins with pad contact and ends with crease of limb. Muscle tension increases and occurs muscle flexion sharing of limb unbend. Second active phase begins with crease and ends with full extension of limb. Jumping load varies considerably depending on player's positions, not only in time, but also in frequency note Vavák (2011). Highest jumping load achieve opposite players, who have on average up to 32,4 jumps per set (Lenhert, 2007).

Most significant improvement of jumping abilities can be achieved in so-called sensitive period. It moves in age range from 9 to 18 years (Šimonek, 1989), while speed component (speed of rebound) improves until 12 or 13 years, while later involved particular strength component (strength of muscles which unbend lower limbs) on increase of explosive strength. It is necessary to include 2 to 4 times in week training focused on development of explosive strength in training process in second part of preparation period (Přidal, Zapletalová, 2010). Major role in development of explosive strength has intensity of loading, which must be maximal (Choutka, Dovalil, 1987; McNelly, Sandler, 2007). Simonek (2007) lists that we can choose different methods for increaising explosive strength level (increasing of muscle mass, improve of intermuscular coordination, intramuscular coordination and increasing of energy supplies). To primary methods in development of explosive strength include repeating methods, eccentric - with small additional load (up to $5 \%$ of own body weight), dynamic efforts and plyometric methods (Choutka, Dovalil, 1987; Sedláček, Lednický, 2010). However, in practice, most used methods are listed plyometric method, speed, isokinetic and contrast methods, which also declare articles of several authors (Matavulj et al., 2001; Kutz, 2008; Horička, 2009; Perič, Dovalil, 2010; Lenhert et al., 2010; Přidal, Zapletalová, 2010; Sedláček, Lednický, 2010. Vavák, 2011). In connection with listed, it is important to point on natural development of explosive strength of lower limbs, which runs during seventh until the eighteenth year of life, with intention to most outstanding changes in age from 11until15 years (Nováková, 1993; Čillík, 1997; Krížová, 2003; Zemková, Pelikán, Dzurenková, 2004). However, some authors disagree with use of plyometric method at this young age for a number of objective reasons, where Faigenbaum (2006) states that if an individual is able to accept councils and also adhere them under vocational supervision, risks are minimalist, similar to normally performed physical activity. Expertly planned and implemented plyometric training unit directed towards significant increase of kinetic performance of youth (Dobrý, 2007). 
Aim. Aim of survey was to verify influence of selected compilation of exercises in sport preparation of pupils in volleyball preparation VK Tatran Banská Bystrica on their explosive strength of lower limbs.

We assume that our selected exercises compilation will change level of explosive strength of lower limbs.

\section{Materials and methods}

Our experimental group was consisted of pupils from volleyball preparations VK Tatran Banská Bystrica, 14 boys $(\mathrm{n}=14)$ in older school age, whose average decimal age was 13,64 years, with an average body height of $172,1 \mathrm{~cm}$ and the average body weight $58,1 \mathrm{~kg}$.

Research was realised in several stages. In first phase (4.9.2013) we have realised input measurements of monitored parameters with respect of all elements with the consequent application of exercises compilation, which are listed in attachment A. Exercises have been applied within sports training in preparatory period by two coaches (L.K. and J.H.) in ZŠ Spojová gym every Monday and Wednesday, mostly at the end of training unit within time period of 15 to 20 minutes approximately. During one micorcycle had pupils 3 training units (Monday, Wednesday, and Friday) at time of 90 minutes and 2 matches on Saturday with a duration of approximately 180 minutes. Consequently, we have performed output measurements (24.3.2014) of monitored parameters. Our experimental group participated at 22 matches and 84 training units. From 84 trainings during our survey used trainers exercises from our exercises compilation in 56 trainings.

Experimental method - field research, pedagogical, one group, one factor with application of experimental multiplier, which was exercises compilation selected by us aimed at changing level of explosive strength of lower limbs.

Measurement method - basic somatic characteristics such as body height, body weight. Plyometry test - (Benedek, Leuciuc, 2010) with measuring instrument Myotest, which we used for detection of lower limbs explosive strength level.

Plyometry test. Starting procedure: adept must have solid shoes with hard soles, test must be carried out on floor, adept must be warmed up and limbered up well before measuring and tested person is first informed with movements of exercise without gear. For higher accuracy of measurements we take every jump five times. After test results are automatically displayed on device display, which shows average of three best performances. After setting device and pin on left side of belt on adept we begin to carry out test.

Aim: measurement of contractionary abilities of lower limbs muscles (flexibility, rigidity or stiffness), reactivity and properties of lower limbs muscles coordination. These values provide us information about explosive qualities, affecting on power of impulses relating to the floor.

Test description: to handle onset of this test adept must be in good shape, without pain of knees or back. Start in a standing position, arms on your hips, head straight forward and motionless position. On signal of device jump directly from stand and consecutively jump from the floor five times, so that you have jumped as high as possible, but to achieve as low as possible time of contact with the ground. At all times arms remain on waist and we jump without bending the knees (fig. 1).
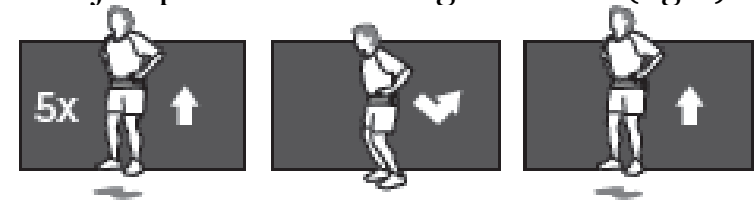

Figure 1: Plyometry test

(http://www.videoanalyza.cz/myotest/testy/80-myotest-skok-plyometrie)

Remove of possible occurring errors: contact time with the floor must be short, significantly shorter than the time spent in the air.

Results: Number of repetitions, height - amount of jump stated in centimetres, Time of contact - the time of contact with the floor stated in milliseconds, Reactivity - if time of contact is shorter, than index of the reactivity is higher, Stiffness - commonly referred as muscular rigidity stated in kilo newtons per metre.

Methods of assessing facts. We have processed qualitative and quantitative data with mathematical statistics methods, supplemented by tables and graphs: arithmetic average, 
frequency analysis, differential, maximum, minimum, variation margin, median and Wilcoxon signed-rank test. Signifikantnce of each changes between input and output evaluation of monitored tests parameters with intention to the level of lower limbs explosive strength we found on standard used level of significance ( $\alpha=0,01, \alpha=0,05)$.

\section{Research results and discussion}

Based on partial aim and tasks, we present part of results, which are subject to further monitoring and treatment presented in tab. 1 and 2. Table 1 shows average, minimum, maximum, median and variation margin of jump height and contact time with floor in plyometry test and in table 2 same mathematical and statistical values of reactivity and muscle rigidity in plyometry test. Since reactivity is closely related to time of contact with floor, we decided to not evaluete graphically this test parameter. Acquired data were therefore evaluated in Figures 2 to 4, in wich are recorded intra-individual results of variation in level of jump height, time of contact with floor and muscular rigidity in plyometry test.

In Table 1 we can see that there was an overall improvement in height of jump in ankle bounces, as evidenced by average value of improvement between input and output evaluation of individual pupil performance by $3,5 \mathrm{~cm}$ (increase of $17,1 \%$ ). We can say that we saw statistically significant changes ( $\mathrm{p}<$ 0,05), thus demonstrating effectiveness of our chosen compilation of exercises on reference determinant, which participates in level height of explosive strength of the lower limbs.

Table 1: Jump height and time of contact with floor in plyometry test $(n=14)$

\begin{tabular}{|c|c|c|c|c|c|c|c|c|}
\hline & \multicolumn{4}{|c|}{ Jump height (cm) } & \multicolumn{4}{c|}{ Time of contact (ms) } \\
\cline { 2 - 10 } & Input & Output & Difference & \% & Input & Output & Difference & \% \\
\hline Average & 27,5 & 31,0 & 3,5 & 17,1 & 144,3 & 141,6 & 2,7 & 1,1 \\
\hline & & & & - & & & & \\
Minimum & 14,7 & 21,2 & -7 & 20,8 & 114 & 106 & -49 & $-41,5$ \\
\hline Maximum & 38,1 & 41,3 & 10,6 & 72,1 & 176 & 179 & 28 & 17,5 \\
\hline Median & 29,3 & 30,4 & 4,35 & 16,2 & 141,5 & 137 & 8 & 6,45 \\
\hline Var. margin & 23,4 & 20,1 & 17,6 & 92,9 & 62 & 73 & 77 & 59,0 \\
\hline
\end{tabular}

In Figure 2 we can see results of jump height in plyometry test. The most significant improvement recorded pupil M.J., which could improve his performance over input test by $10,6 \mathrm{~cm}$ (improvement of up to $72,1 \%$ ). We note, however, three deterioration in performance. Biggest reduction recorded K.L., which is worsened by $7 \mathrm{~cm}$ (decrease of 20,8\%).

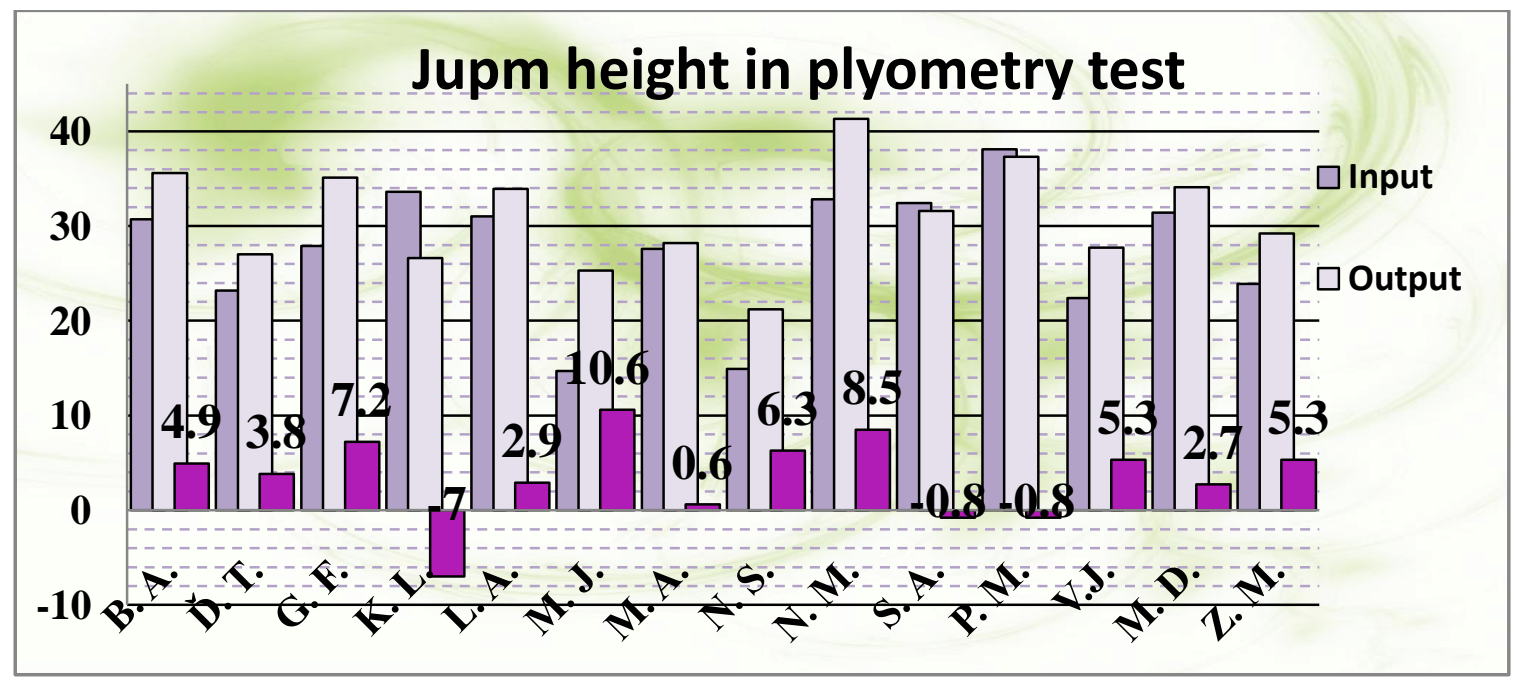

Figure 2: Intra-individual graphic representation of variation in level of jump height in plyometry test $(n=14)$ 
As we can see in table 1, there was also an overall improvement in time of contact with floor at ankle bounces, but this time it was not so considerable. In average, the time of contact with floor in team VK Tatran Banská Bystrica decreased, but we can say that with value of 2,7 ms (change of $1,1 \%$ ) we did not occur statistically significant changes ( $p>0,05)$, thus we did not confirme effectiveness of our chosen compilation of exercises on monitored determinant, which participates in level height of explosive strength of lower limbs.

In Figure 3 we present intra-individual results of the parameter, from which it appears that the largest improvement observed Z.M. He was able to reduce duration of time of contact with floor by $28 \mathrm{~ms}(17,5 \%$ reduction). The most significant extension of time of contact with floor was recorded in M.J., which worsened his performance by $49 \mathrm{~ms}$ (41,5\%).

In average team VK Tatran Banská Bystrica increased reactivity index of 0,05 , increase of $2,1 \%$ (table 2). As mentioned earlier, reactivity is closely related to time of contact with floor, so we can not say anything other than again not reaching statistically significant changes $(\mathrm{p}>0,05)$, thus we did not confirme effectiveness of our chosen compilation of exercises on monitored determinant, which participates in level height of explosive strength of lower limbs. The most significant improvement in this parameter recorded N.S., which increased its reactivity index of 0,4 (change of 18,3\%). The largest negative difference between input and output measurement was found in P.M. He worsened by $-13,1 \%$, representing decrease of reactivity index of 0,45 .

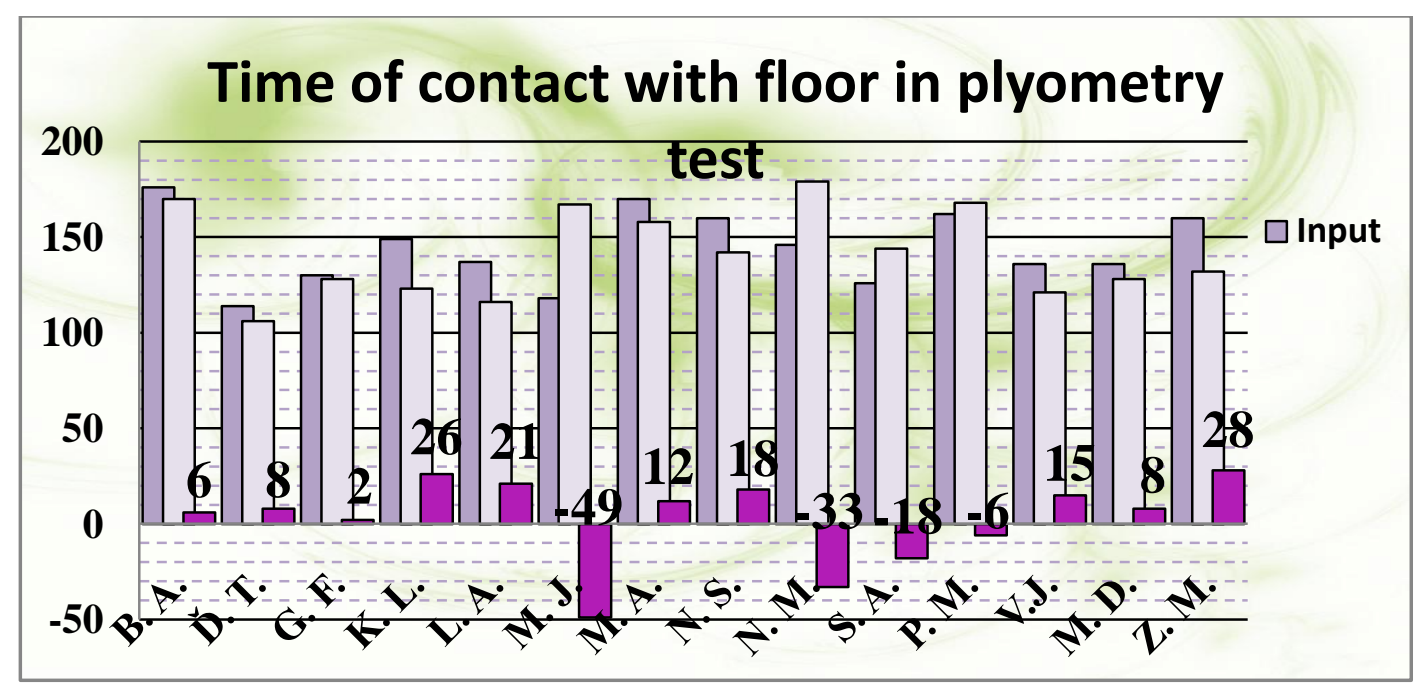

Figure 3: Intra-individual graphic representation of variation in level of time of contact with floor in plyometry test $(n=14)$

In team VK Tatran Banská Bystrica was level of muscle rigidity in plyometry test increased in average of $4,7 \mathrm{kN} / \mathrm{m}$, resulting in positive level increase of $11,3 \%$ (table 2). When comparing level of input and output measurements of muscle rigidity we observed statistically significant changes ( $\mathrm{p}<$ 0,05), thus we reaffirm effectiveness of chosen compilation of exercises to develop listed parameters involved in height level of explosive strength of lower limbs.

Table 2: Reactivity and muscle rigidity in plyometry test $(n=14)$

\begin{tabular}{|c|c|c|c|c|c|c|c|c|}
\hline & \multicolumn{4}{|c}{ Reactivity } & \multicolumn{4}{c|}{ Muscle rigidity (kN/m) } \\
\cline { 2 - 10 } & Input & Output & Difference & \% & Input & Output & Difference & \% \\
\hline Average & 3,3 & 3,3 & 0,05 & 2,1 & 38,0 & 42,7 & 4,7 & 11,3 \\
\hline Minimum & 2,19 & 2,59 & $-0,45$ & $-13,1$ & 26,8 & 19,6 & $-7,2$ & $-26,9$ \\
\hline Maximum & 4,08 & 3,97 & 0,4 & 18,3 & 66,4 & 71,5 & 14,1 & 36,8 \\
\hline Median & 3,45 & 3,24 & 0,14 & 4,13 & 33,7 & 39,75 & 4,45 & 10,3 \\
\hline Var. margin & 1,9 & 1,4 & 0,9 & 31,4 & 39,6 & 51,9 & 21,3 & 63,7 \\
\hline
\end{tabular}


As we can see in figure 4, the most significant decline in level of muscle rigidity occurred in pupil P.M., namely of $7,2 \mathrm{kN} / \mathrm{m}$ (change of -26,9\%). The biggest positive change between input and output evaluation was recorded in B.A., which improved level of his muscle rigidity of $14,1 \mathrm{kN} / \mathrm{m}$ (change of $36,8 \%$ ).

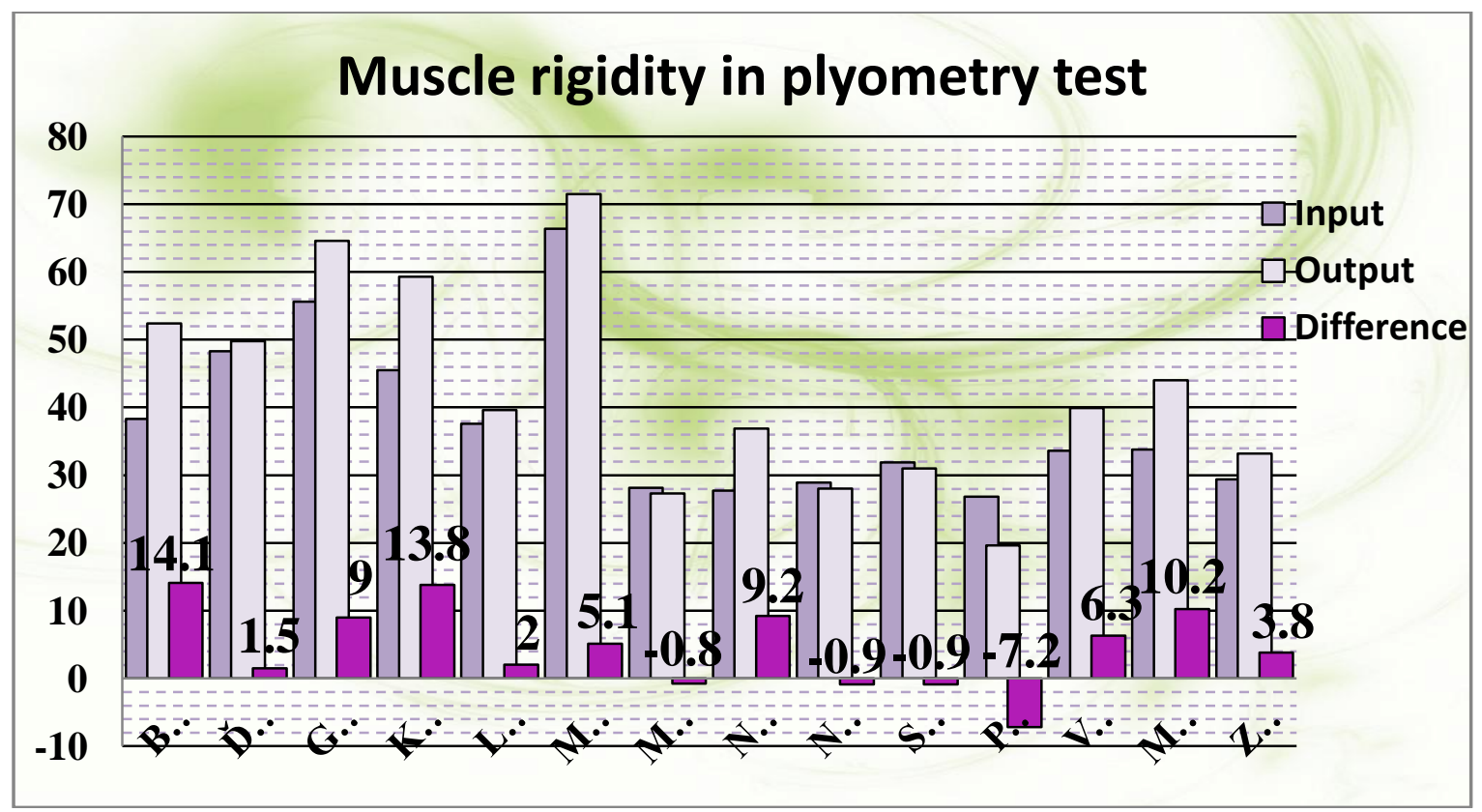

Figure 4: Intra-individual graphic representation of variation in level of muscle rigidity in plyometry test $(n=14)$

\section{Conclusion}

Primary aim of research was to verify effect of our chosen compilation of exercises aimed at developing of explosive strength of lower limbs in pupils of volleyball preparation in VK Tatran Banská Bystrica. Using our measurements, we found that there was an overall increase in level of jump explosiveness in all watched parameters of explosive strength of lower limbs in pupils of volleyball preparation in VK Tatran Banská Bystrica, but in some parameters underlying monitored determinant were these changes minimal, not statistically significant at level of $5 \%$ of significance. Thanks to selected compilation of exercises we have achieved statistically significant $(p<0,05)$ changes in level of jump height and muscle rigidity of lower limbs. We have not achieved, however, statistically significant changes ( $p>0,05$ ) in time of contact with floor and reactivity participated on explosive strength of lower limbs.

Based on these arguments, we can conclude that our hypothesis was not confirmed in this case. As cause of non-fulfilment of hypothesis we see absence of some pupils on training units, mainly longer-term absence on training process due to injuries. Another factor which influenced that hypothesis was not confirmed was fatigue caused by higher training and match load. Most of players are not playing only volleyball, but also other sports, which increased rate of fatigue. Since our research group started training in late August 2013 and the first competitive round was on Schedule in about six weeks later, pupils did not have enough space for development of condition abilities, therefore to develop explosive strength. They had to by focused more on training of techniques and tactics, because they had not previous experience with volleyball. Detecting of level of lower limbs explosive strength of pupils in watched group outlined us direction in which we should go in our continuous training practice, that it is necessary to focus on all factors affecting explosive strength of lower limbs. Our research can be beneficial for other trainers who will apply obtained facts in their volleyball practice.

\section{References:}

1. Benedek, F. \& Leucic, F. V. (2010). Using electronic Device for Muscular Strength Determination. In Electronics and Electrical Engineering [online]. 2010, vol. 1, no. 10 [cit. 2014- 
01-11]. ISSN 1392 - 1215. Dostupné na internete:<http://downloads.myotest.com/ documents/edit_sciences/39_ISSN_1392-121520.pdf>.

2. Dobrý, L. (2007). Plyometrie a mládež - fakta a mýty. In Telesná výchova a sport mládeže. 2007, roč. 73 , č. 3, s. 34-36.

3. Doležalová, L. \& Lednický, A. (2006). Cvičenia na rozvoj reaktívnej sily dolných končatín. In Telesná výchova a šport. Bratislava, 2006, roč. 16, č. 2, s.1-3.

4. Faigenbaum, A. (2006). Plyometrics for kids: facts and fallacies. In NSCA's Performance Training Journal. 2006, vol. 1, no. 2, pp 13-16.

5. Horička, P. (2009). Plyometrické cvičenia ako prostriedok rozvoja odrazovej výbušnosti. In Športový edukator. 2009, roč. 2, č. 2, s. 43-51.

6. Choutka, M. \& Dovalil, J. (1987). Sportovní trénink. Praha : Olympia, 1987. 316 s.

7. Krížová, K. (2003). Úroveň výbušnej sily dolných končatín u tanečníčok klasického tanca. In Telesná výchova a šport. 2003, roč. 13, č. 2, s. 34-36.

8. Kutz, M. (2008). Theoretical and practical issues for plyometric training. In NSCA's Performance Training Journal. 2008, vol. 2, no. 2, pp. 10-12.

9. Lenhert, M. (2007). Současné směry teorie a praxe sportovního tréninku : habilitačná práca. Olomouc: Univerzita palackého, FTK, 2007. 139 s.

10. Lehnert, M. a kol. (2010). Trénink kondice ve sportu. Olomouc: Univerzita Palackého, 2010. 143 s.

11. Matavulj, D. et al. (2001). Effects of plyometric training on jumping performance in junior basketball players. In The Journal of Sport Medicine and Physical Fitness. 2001, vol. 4, no. 1, pp. 159-164.

12.Mcnelly, E. \& Sandler, E. 2007. Power plyometrics: The Complete Program. Aachen: Meyer \& Meyer Verlag, 2007, 155 s.

13.Nováková, H. (1993). Stabilita vývoje explosivních schopností dolných končetin 11-18 letých chlapců. In Telesná výchova a šport. 1993, roč. 3, č. 1, s. 32-36.

14.Perič, T. \& Dovalil, J. (2010). Sportovní trénink. Praha: Grada Publishing, 2010, $160 \mathrm{~s}$.

15.Přidal, V. \& Zapletalová, L. (2010). Volejbal - herný výkon - tréning - riadenie. Bratislava : PEEM, 2010. 181 s.

16.Sedláček, J. \& Lednický, A. (2010). Kondičná atletická príprava. Bratislava : Slovenská vedecká spoločnost’ pre telesnú výchovu a šport, 2010, $168 \mathrm{~s}$.

17. Sýkora, F. a kol. (1995). Telesná výchova a šport. Terminologický a výkladový slovník, 2. zväzok. Bratislava : F.R. \& G. spol. s.r.o., 1995. 402 s.

18. Šimonek, J. (1980). Telesná príprava športovcov. Bratislava : ŠPORT, 1980. $146 \mathrm{~s}$.

19.Šimonek, J. (2007). Rozvoj výbušnej sily dolných končatín v športových hrách. Prešov: Expres Print, 2007. 24 S.

20. Tukel, T. (2012). Air Alert: The Complete Vertical Jump Program - Teaching You How To Jump Higher. Illinois: TMT Sport, 2012. $51 \mathrm{~s}$.

21.Vanderka, M. (2008). Silové a rýchlostno-silové schopnosti v kondičnej príprave športovcov. Bratislava : ICM Agency, 2008. 92 s.

22. Vavák, M. (2011). Teoretické východiská kondičnej prípravy volejbalistov. Bratislava : ICM Agency, 2011. $160 \mathrm{~s}$.

23. Zemková, E., Pelikán, H. \& Dzurenková, D. (2004). Odrazová výbušnost’ dolných končatín u rockenrollistov a jej rozvoj špeciálnymi tréningovými činnostami. In Telesná výchova a sport mládeže. 2004, roč. 70, č. 8, s. 31-33.

24. Zemková, E. \& Hamar, D. (2004). Výskokový ergometer v diagnostike odrazových schopností dolných končatín. Bratislava: PEEM, 2004. $46 \mathrm{~s}$.

25. Zemková, E. \& Hamar, D. (2005). Osobitosti rozvoja odrazových schopností u športovcov špecializácií. In Telesná výchova a šport. 2005, roč. 15, č. 1, s. 42-44. 